our financial system, and the prompt honoring of checks with the resulting reliance on them is necessary to its proper functioning. The public enjoys the convenience, but the banker makes the profit from this arrangement. He encourages this reliance on checks as cash, so there is nothing strange about putting on him the burden of all the injuries which grow out of this reliance and are caused by his negligence or deliberate dishonors which turn out to be wrongful because he mistook his rights. He is the center of this currency system, profits from it and is in a position to distribute the losses.

If there is a well-defined policy of holding the banks liable for all of the proximate injuries resulting from a wrongful dishonor, as there is under the Abramowitz case, the public can put an even stronger reliance on checkswhich is to the benefit of the community at large, and in the long run, to the bankers.

jury which the depositor suffers. In Stella Flour \& Feed Corp. v. Nat'l City Bank, 285 App. Div. 182, 136 N.Y.S. 2d 139 (1st Dep't, 1954), the plaintiff sued for damages to business and credit suffered as a result of his account being depleted by the bank's negligence in cashing checks on which the payees' names had been changed. The complaint was dismissed on the grounds that to grant tort damages would be pushing responsibility beyond the point where commercial and banking people thought it ended. Cf. Abate v. Bushwick Savings Bank, 207 Misc. 372,138 N.Y.S. 2d 140 (N.Y. City Ct., 1955).

Furthermore, one cannot avoid the liquidated sum rule by making checks out to oneself and presenting them at the bank. In Kinlan v. Ulster Bank, Ltd. [1928] Ir. Rep. 171, the plaintiff had attempted to draw on his account by presenting checks made out to himself. In reply to his suit for wrongful dishonor the court said, "the cause of action on the facts is not the wrongful dishonouring of the plaintiff's cheques, but the wrongful refusal to answer his demand for payment to him out of the moneys standing to the credit of his account. From this point of view, the fact that he produced cheque forms . . . is practically immaterial." Ibid., at 182.

The requirement that there be a third party payee automatically limits recovery to situations where the money was intended for a specific purpose. Otherwise the bank would be liable for all of the speculative losses which might be sustained through a lack of funds. Since these losses would be determined by the depositor's testimony as to how he intended to use his money, the action would encourage speculation and fraud. But compare Jones $v$. Citizen's Bank of Clovis, 58 N.M. 48, 265 P. $2 \mathrm{~d} 366$ (1954). This was an action by an administratrix for loss of credit and mental anxiety leading to the depositor's death. In deciding that a physician's testimony was admissible the court related how the decedent, through lack of funds, was forced to sell his furniture, that his wife had to work, and he could not pay his hospital bills. The court thus improperly merged the damage from lack of funds with those arising directly from the dishonor.

\title{
STOCK EXCHANGE MEMBER'S LIABILITY TO CUSTOMER OF OUTSIDE BROKER
}

It is settled law that when a person engages another to transact business for him on a particular market the business will be conducted according to any established custom and usage of that market, whether or not the person 
for whom the business is being transacted is aware of the custom. ${ }^{x}$ There is a limitation to this rule, however: the custom must not be unreasonable. ${ }^{2}$

In the recent case of Lynch v. Mare ${ }^{3}$ the Utah Supreme Court used this doctrine to give effect to a custom of the New York Stock Exchange used as a defense in an action brought by a customer for money had and received. The customer, Lynch, ordered stock through a local stockbroker, one Badger, who in turn placed the order with Hogle \& Co., members of the New York Stock Exchange, with whom Badger had conducted many transactions, all of which were carried by Hogle in one account. Through correspondence in the form of telegrams, Badger was advised by Hogle of the purchase of the stock and of a settlement date. Badger then told Iynch that the stock had been purchased and Lynch paid him in full. Just prior to the designated settlement date Badger made a payment of $\$ 40,000$, which was sufficient to cover the stock in question, which cost $\$ 1,793.45$. The evidence indicates that at this point, had delivery been requested, Hogle would have delivered the stock. It also appears that at this time the account was in balance. ${ }^{4}$ Shortly thereafter Badger died, deeply indebted to Hogle, the indebtedness having arisen from an exchange of checks with Badger's turning out to be bad. ${ }^{5}$ Although the majority did not refer to this exchange, the dissent implies that it represented a loan by Hogle to Badger, Hogle planning to hold Badger's check a while before presenting it. The proceeds from the sale of the stock-which Badger had ordered sold just prior to his death-were applied to this debt. Lynch sued Hogle for the value of the stock, but was denied recovery by virtue of a custom providing that: "[W] hen an exchange seat broker purchases stock for an outside broker and holds such stocks in

${ }^{1}$ Bibb v. Allen, 149 U.S. 481 (1893) ; Ford v. Snook, 205 App. Div. 194, 199 N.Y. Supp. 630 (4th Dep't, 1923), aff'd 240 N.Y. 624, 148 N.E. 732 (1925); Samuels v. Oliver, 130 III. 73, 22 N.E. 499 (1889). For further citations consult Regulations, Rules, Custom or Usage of Stock or Produce Exchange or of Stock or Produce Broker as Affecting Customers, 79 A.L.R. 592, 604 (1932). Consult also 1 Meyer, The Law of Stock Brokers and Stock Exchanges 157 et seq. (1931).

${ }^{2}$ Continental Coal Co. v. Birdsall, 108 Fed. 882 (C.A. 4th, 1901) ; Groskin v. Knight, $290 \mathrm{~Pa} .274,138$ Atl. 843 (1927). Occasionally, courts have considered "unreasonable" to mean contradictory of the common law and have refused to give effect to a custom that conflicts with the law. See, e.g., National Bank v. Burkhardt, 100 U.S. 686 (1879). In discussing this position, Lawson said, "it is obvious that if proof of a usage could be rejected because it established something different from the law, no custom would ever be proved, because if it were not different it would be part of the law." Lawson, The Law of Usages and Customs 465 (1881). While the problem presented by this conflict is beyond the scope of this comment, it is suggested that the better view is that indicated by Lawson.

${ }^{3} 3$ Utah 2d 271, 282 P. 2 d 841 (1955).

- Consult note 5 infra.

"The majority simply stated that Badger died deeply indebted to Hogle. The dissent indicates more fully how the indebtedness arose. Four days after the settlement date, Badger and Hogle exchanged checks; Badger's was for $\$ 34,000$; Hogle's for $\$ 32,000$, Badger receiving a $\$ 2,000$ credit in his account to balance the amounts. 
the latter's account, all of the stocks held therein are pledged to support the outside broker's credit."

In response to the plaintiff's argument that the custom was unreasonable, the court merely said: "[W]e see nothing either unreasonable or illegal in Hogle's conduct which would bring it under the rule contended for by Lynch that the customer should not be bound by any unreasonable or illegal rule or custom of the business." It was not suggested why the custom was reasonable; nor did the court propose any test for measuring its reasonableness. ${ }^{8}$ The sole authority relied upon by the court was Korns v. Thomson \& McKinnon, ${ }^{9}$ which held that the custom created a pledge without inquiring into the reasonableness of the custom. The purpose of this comment is to examine the custom relied upon in Lynch v. Maw and to measure its reasonableness,

'Lynch v. Maw, 3 Utah 2d 271, 273, 282 P. 2d 841, 842 (1955).

'Ibid., at 274, 843.

${ }^{8}$ For a discussion of cases holding similar customs unreasonable consult text infra p. 496.

22 F. Supp. 442 (D. Minn., 1938). In the Korns case the plaintiff had ordered stock through an outside broker who, in turn, requested an exchange broker (the defendant) to execute the order. After the plaintiff had paid the outside broker, but before the stock had been delivered, the defendant sold the stock at the outside broker's direction. On the day of sale the outside broker filed a voluntary petition in bankruptcy. The defendant applied the sale proceeds to debts owing from the outside broker. The outside broker had both a commodity account and stock account with the defendant; the indebtedness arose mainly from losses in the commodity transactions.

While the Federal district court did use the custom in holding for the defendant, it did not consider its reasonableness but merely said that the plaintiff customer "must be held to have contemplated and authorized a course of dealing in accordance with the rules and customs of the New York Stock Exchange." Ibid., at 447. Moreover, the Korns situation differs from the Lynch case in that in the former the indebtedness did not arise from a subsequent debt or loan.

In finding that the custom created a pledge the court in the Korns case adopts an interesting analogy, but one that should not control the situation. In the usual pledge situation-relied upon by the court-a broker wrongfully delivers his customers' securities to third persons for the purpose of receiving credit. It is generally held that the customers cannot get the securities or their value until the pledgee is paid in full. Turnbull v. Longacre Bank, 249 N.Y. 159, 163 N.E. 135 (1928) ; Bennet v. Logan \& Bryan, 80 Cal. App. 571, 252 Pac. 662 (1927); Austin v. Hayden, 171 Mich. 38, 137 N.W. 317 (1912) ; Willard v. White, 56 Hun 581, 10 N.Y. Supp. 170 (1890); Jerome v. McCarter, 94 U.S. 734 (1876). But there is a difference in the mechanics of the transactions involved that destroys the analogy. In the pledge situation the pledgor has in his possession securities of his customers endorsed in blank. Generally, when he pledges them it would appear to the pledgee that he is the owner, and the pledgee usually has no notice of the interest of the customers. For the courts to require a high standard of inquiry would be to destroy the negotiability aspects of share certificates and it is the policy of negotiability that the courts have used to justify their decisions. See Mason v. Public Nat'l Bank \& Trust Co., 262 App. Div. 249, 28 N.Y.S. 2d 416 (1st Dep't, 1941).

In the custom situation the transaction is different. The broker has ordered the purchase of stock for his customer through the defendant. The stock is at all times in the hands of the defendant; there is no issue of negotiability involved. Consequently, to allow the pledge cases to control the Lynch situation is to assume that merely because the parties appear in like roles the results should be the same, without considering the nature of the transaction and the underlying policies involved. 
considering in this regard the common law and market practices.

For the purpose of seeing how the common law would treat the situation, the law of agency must be consulted. Plaintiff Lynch is an undisclosed principal; ${ }^{10}$ the defendant is a third party who has dealt with the agent of the plaintiff and who has set off a debt due from that agent in a suit by the principal. The right of set-off by third parties against undisclosed principals is allowed at common law on the ground that by remaining undisclosed the principal has allowed the agent to appear as the party in interest in the transaction, i.e., he has clothed the agent with the indicia of ownership. ${ }^{11}$ If the agent were as he appeared, the third party could set off any debts in an action by the former, and this right of set-off is not lost by the entrance of a party claiming he was the principal all the time. ${ }^{12}$

The rationale for allowing set-off does not exist, however, where the third party had noticed that the person with whom he was dealing was in fact an agent. Thus, courts have usually held that a person dealing with a broker is not entitled to set-off, since brokers almost invariably act for third parties. ${ }^{13}$ Consequently, had the Lynch case been argued on agency principles alone the result would have been different. While this would not require the court to find the custom in the Lynch situation unreasonable, ${ }^{14}$ the logic behind the set-off and "broker's exception doctrine" does argue against the reasonableness of the custom.

The few cases dealing with customs which purported in similar situations to give a set-off right to persons dealing with brokers have held the custom unreasonable, ${ }^{15}$ apparently on the agency principles mentioned above. In Blackburn v. Mason, ${ }^{16}$ a leading English authority, the custom involved gave

${ }^{10}$ The relationship between a customer and a stockbroker is that of principal and agent. Galigher v. Jones, 129 U.S. 193 (1889); Markham v. Jaudon, 41 N.Y. 235 (1869). Consult generally 1 Meyer, The Law of Stock Brokers and Stock Exchanges 249 (1931).

${ }^{11}$ The leading English cases are Rabone v. Williams, 7 T.R. 360, 2 Eng. Rul. Cas. 391 (1785) and George v. Clagett, 7 T.R. 359, 101 Eng. Reprints 1019 (1797). The American courts have accepted this principle. E.g., New Jersey Steam Navigation Co. v. Merchant's Bank, 6 How. (U.S.) 343 (1848).

${ }^{12}$ Nichols v. Martin, 35 Hun (N.Y.) 168 (1885) ; Baring v. Corrie, 2 B. \& Ald. 137, 106 Eng. Reprints 317 (1818).

13 "Hence, if the character of the seller is equivocal-if he is known to be in the habit of selling sometimes as principal and sometimes as agent, a purchaser . . . is bound to inquire in what character he acts in the particular transaction; and if the buyer chooses to make no inquiry, and it should turn out that he has bought of an undisclosed principal, he will be denied the benefit of his set-off." Miller v. Lea, 35 Md. 396, 406 (1871); Baxter v. Sherman, 73 Minn. 434, 76 N.W. 211 (1898); Baring v. Corrie, 2 B. \& Ald. 138, 106 Eng. Reprints 317 (1818); 2 Mechem, Agency $\$ 2492$ (2d ed., 1914).

14 Consult note 1 supra.

${ }^{15}$ Cases discussed note 20 infra. But cf. Korns v. Thompson \& McKinnon, 22 F. Supp. 442 (D. Minn., 1938), discussed note 9 supra.

${ }^{18} 68$ L.T.N.S. 510 (1893). 
"a London broker [who] is employed directly by a country broker ... the right of treating the country broker as a principal, although acting for some one else ... therefore [entitling] the London broker ... to use any claim he may have against the country broker as a set-off against his principal."17 The Court of Appeal indicated that the defendant London brokers knew that the plaintiff was the principal, a power of attorney on the stock sold in the transaction having been executed by the plaintiff and sent to the defendant. It viewed the custom as a bald attempt to achieve set-off against the principal for a debt owed by the agent even though the latter was known as an agent by the third party.

The Blackburn court cited Pearson v. Scott ${ }^{18}$ as supporting its position. In the Pearson case the custom said that a London stockbroker (defendant) was bound only to recognize the person actually employing and instructing him, and from this he claimed the right of set-off. There was some evidence that the defendant knew that the plaintiff, rather than the broker with whom he dealt, was the principal. In the court's opinion, a custom allowing the defendant to pay for his purchase by setting off a debt due him from the plaintiff's broker, "is a custom to pay one man's debts out of another man's money." 19 Such a statement could generally apply to undisclosed principal set-off. However, it is reasonable to assume that the court was not enraged at this type of set-off generally but rather at the pleading of a custom which purported to give that defense where there was notice of the agency and consequently no justification for set-off. In the other cases-predominately English-holding similar customs unreasonable, ${ }^{20}$ the facts likewise indicate that the defendants trying to take advantage of such customs had actual notice of the brokers' agency.

Of this line of authority the Lynch court considered only the Blackburn case. ${ }^{21}$ It refused to follow that case apparently because it was English law

17 Ibid., at 511.

${ }^{18} 9$ Ch. 198, 47 L.J. Ch. 705 (1878).

19 Ibid., at 209, 710.

${ }^{20}$ Evans v. Waln, $71 \mathrm{~Pa} .69$ (1872); Crossley v. Magniac, 1 Ch. 594 (1893) (both dealing with stock transactions) ; Cooper v. Strauss \& Co., 14 T.L.R. 233 (1898) (dealing with the hop market); see Baxter v. Sherman, 73 Minn. 434, 76 N.W. 211 (1898). A custom that allowed insurance underwriters to set off debts due them from brokers in paying losses on policies had earlier in the nineteenth century been held unreasonable. Sweeting v. Pearce, 7 C.B. (N.S.) 449 (1859), aff'd 9 C.B. (N.S.) 534 (1861) ; Scott v. Irving, 1 B. \& Ald. 605 (1830); Todd v. Reid, 4 B. \& Ald. 210 (1821). See Montagu v. Forwood, 2 Q.B.350, 69 L.T. 371 (1893).

27 The majority stated that Blackburn was the only case supporting the plaintiff's contention. It apparently overlooked the authorities cited, notes 18 and 20 supra. In fact, the most violent judicial attack on a similar custom was made by an American court in Evans v. Waln, $71 \mathrm{~Pa} .69,75$ (1872), wherein it was said: "If there is a custom among stockbrokers, when dealing with others, to appropriate money belonging to the principal to the payment of his broker's indebtedness, the sooner it is abolished the better: Malus usus est 
which "may or may not be correlated realistically to present American business customs."22 What is meant by this latter statement is not clear. Certainly the wording of the two customs implies a difference in meaning. The Blackburn custom looks toward set-off as a defense for London brokers; the Lynch custom seems to establish a protective security device. ${ }^{23}$ However, the effect the Lynch court gave to this security measure realizes the same result the Blackburn custom would achieve: One broker is allowed to satisfy a debt due from another broker with securities belonging to a customer of the latter. An analysis of modern stock transactions will indicate that the result of giving effect to the custom as applied in the Lynch situation is unreasonable.

Most stock transactions between correspondent brokers are on margin; i.e., the order comes in, it is filled, and full payment is made at a later date. Until the time of payment the exchange broker is extending credit to the outside broker; should there be a defalcation by the latter, it is only fair to allow the exchange broker to treat the purchased stock as supporting this credit. ${ }^{24}$ This is so, regardless of knowledge that a customer is behind the outside broker. The exchange broker has extended the money for the purchase or has become irrevocably bound to pay another; if he is not reimbursed, he should be allowed to put the stock towards reimbursement. The party for whom the outside broker ordered the purchase should have no remedy against the exchange broker. It is the same case as where a principal gives money to an agent for the purchase of goods and the agent in turn orders the goods from another and then disappears with the money. As the principal bears the risk of the agent's honesty, he cannot collect from the third party. Likewise, the custom guarantees that the risk of defalcation prior to payment to the exchange

abolendus. A custom so iniquitous can never obtain the force or sanction of law, and the marvel is that it should be set up as a defense to this action."

2 Lynch v. Maw, 3 Utah 2d 271, 275, 282 P. 2d 841, 843 (1955).

23 The usage in the insurance cases, note 20 supra, clearly points up this difference. That usage was merely a method of facilitating the cash payment aspect of transactions between brokers and underwriters. The broker, acting for a principal, would get a policy from an underwriter with whom he had an account. The premium payments were not sent by the broker to the underwriter, but rather the broker's account was debited with the amounts due, and any loss on a policy was charged against these amounts due, the remainder being sent to the broker to remit to the principal with the broker making up the difference. When the broker became insolvent defendants pleaded that the usage should excuse them from paying the principal, even though the defendants knew that the plaintiff was the principal in the transaction. See Sweeting v. Pearce, 7 C.B. (N.S.) 449 (1859), aff'd 9 C.B. (N.S.) 534 (1861) for a full explanation of the situation.

${ }^{24}$ The court in the Lynch case indicates, inadvertently perhaps, that this was the purpose of the custom. In stating the facts of the case, the court at one point says that Hogle purchased the stock and held it 'in Badger's 'omnibus account' in pledge to support its [the stock's?] credit, as permitted by broker's custom." Lynch v. Maw, 3 Utah 2d 271, 272, 282 P. 2d 841,842 (1955). 
broker shall be on the party behind the outside broker and not on the exchange broker. Applied this way, the custom is reasonable.

Its reasonableness is far from apparent, however, when after the stock has been paid for the custom is relied upon to justify set-off on a subsequent debt. This, it will be remembered, was the situation in the Lynch case. The exchange broker would deliver the stock upon payment. But delivery of the stock is not requested; it remains in the account. The outside broker requests an extension of credit. The stock in the account will probably be a basis for giving the credit ${ }^{25}$ and it will serve as security. However, the exchange broker knows that the outside broker more times than not is acting for a principal. It does not seem unreasonable that he should inquire into the ownership of any stock in the account which is already paid for. He is now taking a risk by extending credit in the form of a loan; if he wishes protection against undisclosed principals he should inquire into the ownership behind any stock he plans to hold as security for the loan.

To hold that the custom destroys the neecssity for such inquiry, and that the custom can be used as a means of protecting the exchange broker in such a situation, is to give the custom unreasonable effect. Such doctrine encourages exchange brokers to extend credit to outside brokers on security they have reason to believe belongs to someone else. The Utah Supreme Court has given too broad an application to the custom. It has allowed a custom which has as its purpose protection of brokers in margin transactions to aid "a broker in financing a private transaction with the assets of the customers of the Stock Exchange." ${ }^{26}$ Applied this way, the custom is unreasonable.

${ }^{5}$ The dissent in the Lynch case points out that Hogle was either relying on the stock in the account, or on Badger personally, when the advancement was made.

${ }^{20}$ Dissenting opinion, Lynch v. Maw, 3 Utah 2d 271, 277, 282 P. 2d 842, 845 (1955).

\section{SPECIFICATION AND APPORTIONMENT CONTRACTS: COMMON LAW AND UNIFORM COMMERCIAL CODE}

Commercial transactions often require a degree of flexibility which is best achieved by leaving open for subsequent determination certain terms of the agreement. A familiar open term arrangement is found in the specifications and apportionment agreement. Typically, in such an agreement the total quantity of merchandise to be purchased is stated, ${ }^{1}$ the buyer having power to specify certain stated sizes, styles, or qualities which vary from a base price according to a list of differentials.

${ }^{1}$ Occasionally the quantity is measured in dollars, as, for example, in Bowen v. Virginia Lee Candies, 44 S.W. 2d 502 (Tex. Civ. App., 1931), wherein the buyer had promised to purchase to the extent of $\$ 60$ per month. 